\title{
The Impact of Economic Growth and Human Development Index on Poverty in Riau Province
}

\author{
Ellyan Sastraningsih M. Irfan Rosyadi Willy Dio Prakoso \\ Department of Economic Development, University of Islam Riau \\ Kaharuddin Nasution Street No. 113. Pekanbaru city. Riau Province. Indonesia
}

\begin{abstract}
Poverty is a main problem for growth especially in a developing country, Indonesia. The government's effort to overcome a poverty problem by encouraging economic growth and a living standard through improvement in the Human Development Index tends to be off target, so the population living below the poverty line is still found. This research analyses The Impact of Economic Growth and Human Development Index on Poverty in Riau Province in 2010-2018 via a quantitative analysis method with panel data regression. The result of this research shows Economic growth has no significant effect on poverty, while the Human Development Index has a significant negative effect on poverty.
\end{abstract}

Keywords: Poverty, Economic growth, Human Development Index, Panel data regression

DOI: $10.7176 / \mathrm{JESD} / 11-4-18$

Publication date: February $29^{\text {th }} 2020$

\section{Introduction}

Poverty is a classical problem occurred in some countries in the world especially developing countries such as Indonesia. Indonesia is one of 193 countries included in Sustainable Development Goals (SDGs) previously known as Millennium Development Goals (MDG's) signed in 2000 having purpose in Poverty reduction - one of the main objectives of the 17 goals agreed in MDGs.

A poverty problem is a state responsibility as noted in the 1945 Constitution of the Republic of Indonesia Article 34. Indonesia focuses on poverty reduction through National Long-term Development Plan of Indonesia 2005-2025. Various rules and programs cooperating in a synergy create a great effort to reduce poverty. National Team for the Acceleration of Poverty Reduction is a coordination forum formed by the president in 2010 to deal directly with problems faced in the process of poverty reduction. At the regional level, a Regional Poverty Reduction Strategy is prepared which refers to Minister of Home Affairs Regulation number 42 of 2010 concerning a Provincial and Regency/City Poverty-Reduction Coordination Team.

Central bureau of statistic states the aggregate of Indonesian poor society from 2010 to 2018 shows a decrease of 5.35 million people from 31.02 million in 2010 to 25.67 million in 2018. It means that poverty reduction has been achieved by Indonesian country, although 25.67 million people are still classified as quite a large number of poor people.

Averagely, the poverty level in Riau is below the national poverty level as Riau province has achieved a national target stated in the National Medium-Term Development Plan 2010-2014, a poverty rate of 9.0-10.0, and the National Medium-Term Development Plan 2015-2019, a poverty rate of 6.0-8.0. The reduction of poverty level in Riau Province 2010-2018 is 2.62 in accordance with the data, 10.01 in 2010 and 7.39 in 2018.

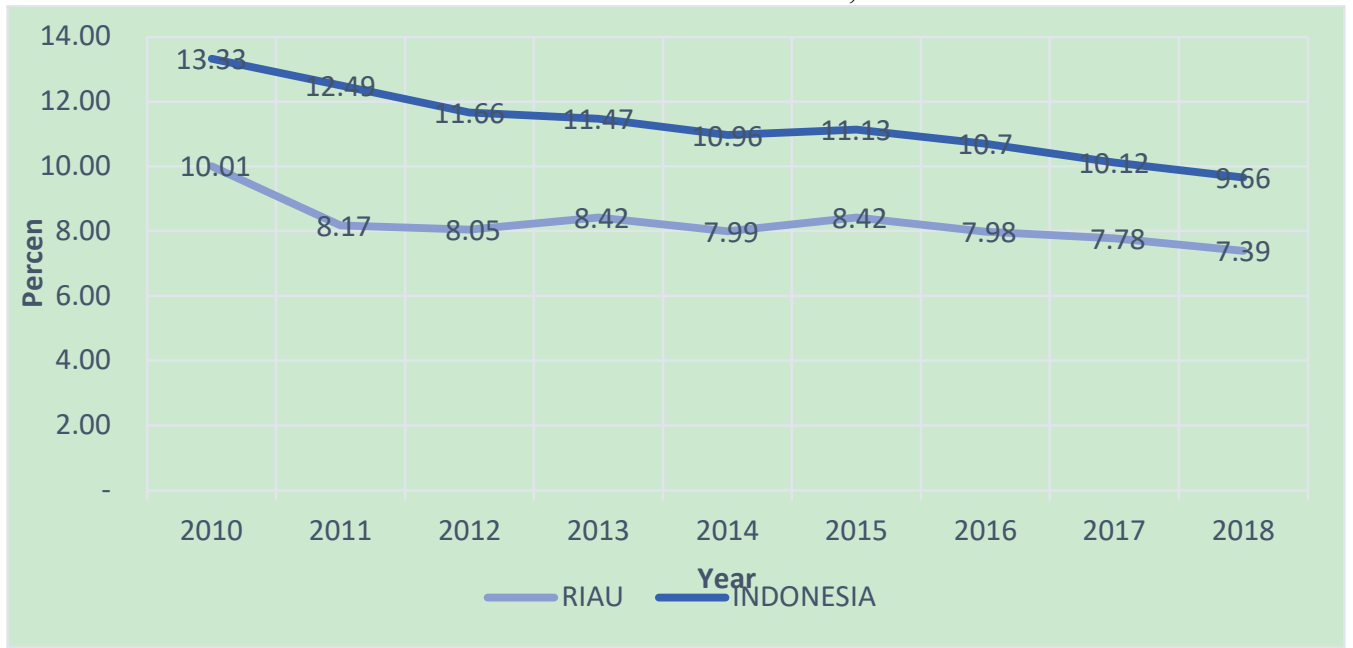

Figure 1, Indonesian and Riau poverty level in 2010-2018 (percent)

Source: Central Statistics Agency of Riau Province (2019)

Based on Regional Medium-Term Development Plan of Riau province, Riau achievement plan for poverty 
reduction is above the national target, namely 8 percent in 2010-2014 and $6-7$ in 2015-2019. Based on the poverty data of Riau province in picture 1, the target of poverty reduction in Riau province is not fully achieved; it indicates the government is not serious and effective to reduce poverty in Riau. Besides, the government does not focus on doing the poverty-reduction program in a determinant sector affecting the poverty; therefore, there are 500.44 thousand poor people in Riau in 2018.

Table 1. Number of poor population by regency/city in Riau province in 2010-2018

\begin{tabular}{|l|c|c|c|c|c|c|c|c|c|}
\hline \multirow{2}{*}{ Regency/City } & \multicolumn{7}{|c|}{ Number of regency/city poor people (thousands people) } \\
\cline { 2 - 10 } & $\mathbf{2 0 1 0}$ & $\mathbf{2 0 1 1}$ & $\mathbf{2 0 1 2}$ & $\mathbf{2 0 1 3}$ & $\mathbf{2 0 1 4}$ & $\mathbf{2 0 1 5}$ & $\mathbf{2 0 1 6}$ & $\mathbf{2 0 1 7}$ & $\mathbf{2 0 1 8}$ \\
\hline Kuantan Singingi & 36.70 & 31.07 & 31.26 & 34.71 & 33.52 & 34.10 & 31.22 & 31.95 & 32.10 \\
\hline Indragiri Hulu & 32.50 & 27.51 & 27.68 & 29.60 & 29.40 & 31.63 & 29.73 & 29.42 & 27.22 \\
\hline Indragiri Hilir & 62.40 & 52.82 & 53.01 & 54.18 & 52.39 & 56.85 & 56.82 & 55.40 & 51.42 \\
\hline Pelalawan & 44.40 & 37.59 & 38.28 & 43.55 & 42.67 & 47.53 & 45.35 & 44.40 & 44.29 \\
\hline Siak & 24.60 & 20.83 & 21.04 & 23.21 & 22.54 & 24.81 & 24.86 & 26.83 & 25.81 \\
\hline Kampar & 72.30 & 61.20 & 61.75 & 68.58 & 67.61 & 72.22 & 67.68 & 66.33 & 69.32 \\
\hline Rokan Hulu & 62.40 & 52.82 & 53.55 & 59.85 & 58.29 & 64.74 & 67.42 & 69.24 & 72.28 \\
\hline Bengkalis & 41.30 & 34.96 & 35.25 & 40.11 & 38.82 & 40.00 & 37.49 & 38.19 & 35.11 \\
\hline Rokan Hilir & 51.70 & 43.77 & 44.02 & 47.47 & 46.07 & 49.13 & 52.40 & 53.19 & 48.92 \\
\hline Kep. Meranti & 75.00 & 63.58 & 63.85 & 64.02 & 61.07 & 61.64 & 56.18 & 53.05 & 51.17 \\
\hline Pekanbaru & 38.20 & 32.34 & 32.66 & 32.46 & 32.29 & 33.76 & 32.49 & 33.09 & 31.62 \\
\hline Dumai & 16.50 & 13.97 & 14.11 & 13.72 & 13.62 & 14.97 & 13.76 & 13.53 & 11.19 \\
\hline Riau & 558.00 & 472.45 & 476.46 & 511.47 & 498.28 & 531.39 & 515.40 & 514.62 & 500.44 \\
\hline
\end{tabular}

Source: Central Statistics Agency of Riau Province (2019)

Even though the poverty level is below the average of a national poverty level, the poverty in Riau province becomes a problem of itself with economic growth slowing in 2010 of 4.21 percent to 2.34 percent in 2018. This decreased economic growth is caused by a change in the economic structure of Riau province from the mining and quarrying sector to the manufacturing sector. Falling oil price has caused the decline in mining and quarrying sector growth.

Not only economic growth but a human development index also has an important role to reduce the poverty since the height of Human Development Index is expected to increase the productivity of the population to work so that they can get out of the poverty line as well as the increasing number of productive ages in Riau province that can give a positive impact on the poverty reduction.

The correlation between economic growth and a human development index becomes the main measure in the process of poverty reduction in Riau province. Generally, the increasing of economic growth and a human development index can reduce the poverty level. The synergy between government, regional government, society, and a private part is needed to achieve the poverty reduction. The analysis for the impact of economic growth and a human development index on poverty reduction in Riau province in 2010-2018 is needed in order that it can become literature in establishing poverty-reduction policies.

\section{Literature Review}

Amartya sen (1981) states poverty is the absence of one or several basic abilities needed to obtain adequate food, clothing and shelter as well as access to health and education. Amartya sen also believes that it cannot necessarily draw a poverty line and then apply it thoroughly for all people in the same way without taking into account personal characteristics and conditions.

According to World Bank, "Poverty is hunger, Poverty is the absence of a place to live, and Poverty is sick and unable to see a doctor. Poverty is not having access to school and not knowing how to read. Poverty is not having a job and worrying about life in the future. Poverty is the loss of a child due to a disease caused by unclean water. Poverty is powerlessness, lack of representation and freedom".

The Central Statistics Agency (2019) defines poverty is the inability of people to meet basic needs approach in terms of the economy of both food and non-food with the average size of expenditure per capita every month below the poverty line.

The poverty measure based on the method used by the Central Statistics Agency (2019), is the poverty line while the poverty rate is measured using the concept of Head Count Index (HCI-P0) or calculating the number of poor people below the poverty line.

The Human Development Report (HDR) and the Central Statistics Agency of Riau province (2019) state that "Human development is a process to increase the choices that humans belong to. Among the many choices, the most important choices are to live long and healthy, to be knowledgeable, and to have access to the resources needed to live properly". 


\section{Methodology}

This research has used quantitative method with secondary data collected from the data provider agency, Central Bureau of Statistics. The compiled data have been analyzed by using the method as follows.

\subsection{Data panel Method}

Analysis of Panel data is the data combination between time-series data and cross-section data. Time-series data is data taken from an object in several time periods and time-series data used in this research are poverty-level data in percent in 2010-2018, economic-growth data or growth rate of Gross Regional Domestic Product at the basis of the constant price 2010 in percent in 2010-2018, and Human Development index data in index 2010-2018 while cross-section data is data taken from many objects in one time period and the cross-section data used in this research are data of 10 districts and 2 cities in Riau province.

Panel data have been used in this research since they have some advantages, namely first, panel data is a combination of time-series data and cross-section data that can provide more data so as to produce a greater degree of freedom and second, a combination of time-series data and cross-section data information that can overcome the problem of omitted variables (Widarjono, 2018).

In the analysis of panel data model, there are three well-known approaches, namely common-effect method, fixed-effect method, and random-effect method. First, Common Effect is the simplest method for estimating panel data by simply combining time-series data and cross-section data with the Ordinary Least Squares (OLS) method. This method is assumed that the behavior data between spaces is same in various periods of time. Second FixedEffect, this method assumes that the regression coefficient (slope) remains between space and time. In the estimation, the fixed-effect model can be done by using dummy to explain the differences in the intercept. This estimation model is often called Least Squares Dummy Variables (LSDV) and fixed-effect method with crosssection weights is used if the heteroscedasticity exists. Third Random-Effect, this method selects the estimation of the panel data with residuals that may be interconnected between time and individuals by assuming each region / region has an interception; however it is assumed that the intercept is a random variable (Widarjono, 2018).

In the estimation of panel data, There are two stages of selection model, namely chow test and hausman test.

1) Chow Test

This test is used to choose Common-Effect Model without dummy variable or Fixed-Effect Model.

2) Hausman test

This test is used to compare between Fixed-Effect model and Random-Effect model which are better for use in model selection.

There are several stages of testing used, namely:

1) Partial Testing (t-statistic test)

T-statistic test is used to find out the significant level of independent variables on the dependent variable individually. The t-statistic test in a multiple regression has a degree offreedom (df) that depends on the number of independent variables added by constants. In this test, the significance level $(\alpha)$ is $5 \%(0.05)$. T-statistic testing criteria are as follows:

If the $t$-statistic probability value is $\geq 0.05$, it means that the independent variable does not affect the dependent variable significantly. While if the t-statistic probability value is $\geq 0.05$, it means that the independent variable influences the dependent variable significantly

2) Simultaneous Testing (f-statistical Test)

This test aims to determine the effect of independent variables together to influence the dependent variable. fstatistical Test are as follows:

If the f-statistical significance value is $\geq 0.05$, it means that the independent variables simultaneously do not significantly influence the dependent variable while If the f-statistical significance value is $\leq 50.05$, it means that the independent variables simultaneously affect the dependent variable significantly.

3) Determination Coefficient (R-square)

Coefficient of Determination (R-square) is a quantity used to measure the suitability of the regression line, which gives the proportion or percentage of total variation in the dependent variable explained by the independent variable. The greater the value of R-square is, the greater the variation of the dependent variable that can be explained by the variation of the independent variables is. The smaller the value of R-square is, the smaller the variation of the dependent variable that can be explained by the independent variables is.

The panel equation in this study is as follows:

Explanation:

$$
\mathrm{Y}_{\mathrm{it}}=\beta_{0}+\beta_{1} \mathrm{X}_{1 \mathrm{it}}+\beta_{2} \mathrm{X}_{2 \mathrm{it}}+\mathrm{e}_{\mathrm{it}}
$$

Y : Poverty Level (Percent)

$X_{1}$ : Economic Growth (Percent)

$X_{2}$ : Human Development index (Index)

e : Disturbing / residual variables (error term) 
$i$ : Observation (Object)

$t$ : Time (Year)

$\beta_{0}:$ Constant

$\beta_{1}, \beta_{2}$, The coefficient of each independent variable

\section{Discussion}

4.1 The Result of Data Panel Regression

The results of the panel data model selection stage are as follows:

1) Chow Test

This test is used to select the model that will be used between the Common-Effect estimation model or the Fixed-Effect estimation model. This test can be done by looking at $p$-value. If it is significant at alpha $\leq 0.05$, the model used is Fixed-Effect but if the p-value is not significant $\geq 0.05$, the model used is the CommonEffect estimation model (Widarjono, 2018). Table 2 shows that $p$-value (probability) is $0.0000(\leq 0.05)$, so the good model used is the fixed-effect model.

Table 2. Chow test

\begin{tabular}{|l|r|r|r|}
\hline \multicolumn{5}{|l|}{ Redundant Fixed Effects Tests } \\
\hline Equation: Untitled \\
\hline Test cross-section fixed effects & Statistic & d,f, & Prob, \\
\hline Effects Test & 229,813355 & $(11,94)$ & 0,0000 \\
\hline Cross-section F & 359,464784 & 11 & 0,0000 \\
\hline Cross-section Chi-square &
\end{tabular}

Source: a result of processed data using Eviews 9.0 (2019)

2) Hausman Test

This test is used to select the model that will be used between the Fixed-Effect estimation model or the Random Effect estimation model. This test can be done by looking at $p$-value. If it is significant at alpha $\leq 0.05$, the model used is the fixed-effect model but if the $p$-value is not significant $\geq 0.05$, the model used is the randomeffect estimation model (Widarjono, 2018). In table 3, Hausman test shows that p-value (probability) is 0.3440 $(\geq 0.05)$ so the good model is a random effect model.

Tabel 3.Hausman test

\begin{tabular}{|c|c|c|c|}
\hline Correlated Random Eff & & & \\
\hline Equation: Untitled & & & \\
\hline Test cross-section rand & & & \\
\hline Test Summary & Chi-Sq, Statistic & Chi-Sq, d,f, & Prob, \\
\hline Cross-section random & 2,134184 & 2 & 0,3440 \\
\hline
\end{tabular}

Source: a result of processed data using Eviews 9.0 (2019)

The result of a good model selection for panel data regression is a random-effect model. The result of panel data regression using the random-effect model is as follows.

Table 4. The result of panel data regression using random-effect model

\begin{tabular}{|c|r|r|r|l|}
\hline Variable & Coefficient & Std, Error & t-Statistic & Prob, \\
\hline $\mathrm{X} 1$ & $-0,033665$ & 0,051683 & $-0,651380$ & 0,5162 \\
\hline $\mathrm{X} 2$ & $-0,559494$ & 0,083386 & $-6,709701$ & 0,0000 \\
\hline $\mathrm{C}$ & 48,67432 & 6,121126 & 7,951858 & 0,0000 \\
\hline R-squared & 0,311265 & & & \\
\hline F-statistic & 23,72674 & & \\
\hline Prob(F-statistic) & 0,000000 & & \\
\hline
\end{tabular}

Source: a result of processed data using Eviews 9.0 (2019)

Random Effect Model is a model that will estimate panel data where interruption variables may be interconnected between time and individuals. In the Random Effect model, intercept differences are accommodated by the error terms of each object. This model is also called the Generalized Least Square (GLS) technique.

The following is the result of testing stage:

1) T-statistic Test

The t-statistic test is used to find out the significant level of the independent variables on the dependent variable individually. Based on table 4, the result of the t-statistic test has stated that the probability of economic growth $(\mathrm{X} 1)$ is $\geq 0.05$. It means that economic growth has no significant effect on a poverty level (Y).

2) F-statistic Test

F-statistic Test is used to determine the effect of the independent variables together affecting the dependent variable. From the estimation result of the panel data in table 4 , it is known that the probability of f-statistic 
is $0.000000(\leq 0.05)$. It means that the level of economic growth and the human development index together affect the level of poverty.

3) R-Square $\left(\mathrm{R}^{2}\right)$

$\mathrm{R} 2$ is the proportion or percentage of the total variation in the dependent variable explained by the independent variable. The panel data estimation result shows that $\mathrm{R}$ is $0.311265(0.31)$. It means that the independent variable can explain the dependent variable by $31 \%$ while the rest is explained by other variables that are not included into the model.

\subsection{Effect of Economic Growth on Poverty}

The effect of economic growth (X1) on a poverty level (Y) based on the result of panel data regression using the random-effect model on table 4 shows the regression coefficient is -0.033665 . It means that economic growth has a negative effect on the poverty level. The effect is not significant at alpha $0.05(5 \%)$. This result is suitable with the result of the research that was conducted by Susilowati (2015) that studied poverty in Indonesia in 2007-2013 and Prasetyoningrum and Sukmawati (2018) that studied poverty in Indonesia in 2013-2017. In that study, it was found that economic growth did not have a significant effect on poverty, so if economic growth increased it could not change the income of the poor to get out of the poverty zone. This means that economic growth does not favor the poor.

The economic growth does not affect the poverty rate in Riau province because the average economic growth has fallen from 2010 - 2018 (figure 2), and the poverty rate is in a downward trend, so that the coefficient of regression results that are negative has no significant effect. The declining economic growth of Riau province is caused by the main economic sectors, namely the mining and quarrying sectors, which have decreased productivity due to falling world oil and gas prices.

The decline in economic growth has occurred in several regencies/cities that are dominant in the mining and quarrying sectors, such as Bengkalis Regency from 2012-2018 there was a negative economic growth (recession), Siak District in 2010-2011 and in 2013-2015 it experienced negative economic growth, and other regencies and cities the economic growth tended to be volatile.

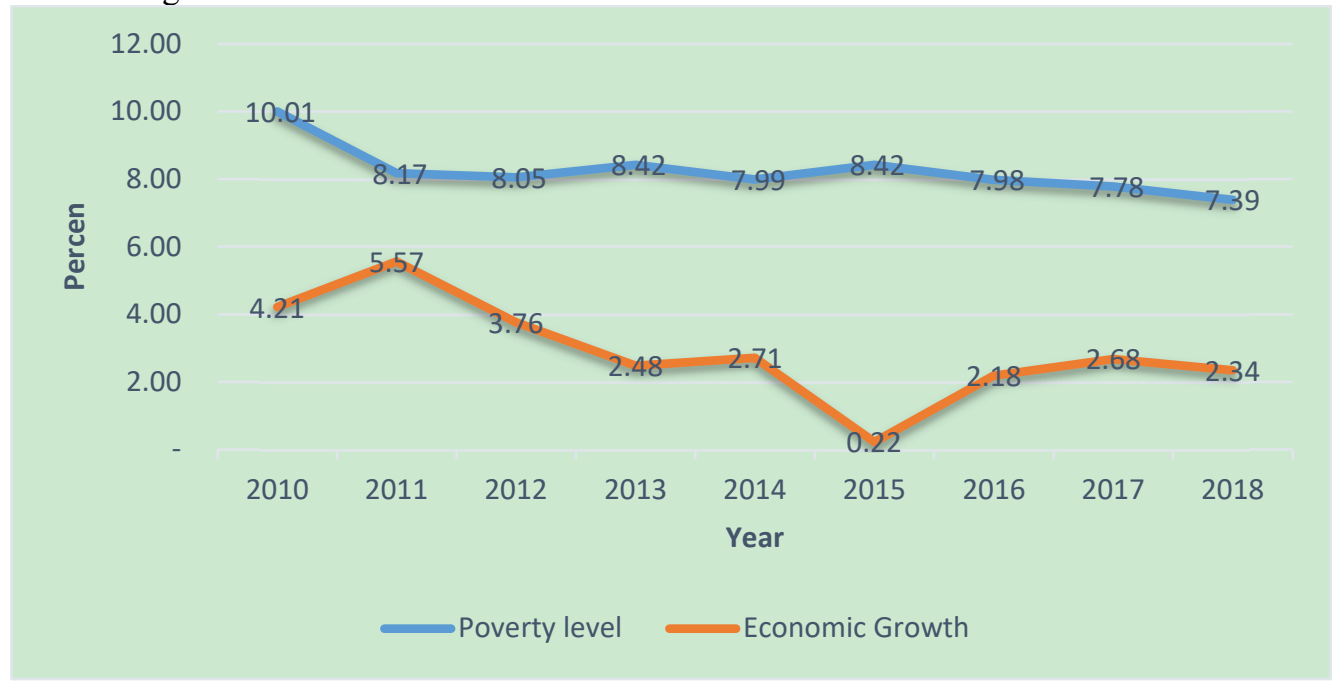

Figure 2, Economic growth and poverty level in Riau Province

Source: Central Statistics Agency of Riau Province (2019)

The manufacturing and agricultural sectors, which must support economic growth in each region, in lieu of the mining and quarrying sectors, which previously contributed to economic growth, has caused the slowing down of economic growth so that the government must be dominant to determine policies quickly in response to the decline in economic growth so as not to have a major impact on regional development. 
Table 5. Growth Rate of Gross Regional Domestic Product at the Base of the 2010 by Regency/City in Riau

Province in $2010-2018$

\begin{tabular}{|l|r|r|r|r|r|r|r|r|r|}
\hline \multirow{2}{*}{ District/City } & \multicolumn{7}{|c|}{ Growth Rate of Gross Regional Domestic Product at the Base of the 2010 by } \\
\cline { 2 - 11 } & $\mathbf{2 0 1 0}$ & $\mathbf{2 0 1 1}$ & $\mathbf{2 0 1 2}$ & $\mathbf{2 0 1 3}$ & $\mathbf{2 0 1 4}$ & $\mathbf{2 0 1 5}$ & $\mathbf{2 0 1 6}$ & $\mathbf{2 0 1 7}$ & $\mathbf{2 0 1 8}$ \\
\hline $\begin{array}{l}\text { Kuantan } \\
\text { Singingi }\end{array}$ & 7.03 & 4.17 & 5.93 & 5.47 & 5.14 & -2.14 & 3.88 & 4.43 & 4.65 \\
\hline Indragiri Hulu & 5.69 & 5.25 & 8.39 & 6.21 & 5.53 & -2.94 & 3.68 & 4.02 & 3.47 \\
\hline Indragiri Hilir & 7.31 & 7.16 & 7.91 & 7.17 & 6.88 & 2.05 & 4.68 & 4.56 & 3.59 \\
\hline Pelalawan & 6.71 & 5.73 & 3.02 & 5.55 & 6.20 & 2.46 & 2.96 & 4.10 & 3.75 \\
\hline Siak & -8.81 & -0.52 & 2.07 & -2.33 & -0.97 & -0.21 & 0.35 & 0.94 & 1.09 \\
\hline Kampar & 3.03 & 4.11 & 5.82 & 6.31 & 3.43 & 1.09 & 2.80 & 3.01 & 1.90 \\
\hline Rokan Hulu & 4.75 & 6.88 & 6.12 & 5.99 & 6.50 & 1.98 & 4.77 & 5.43 & 4.17 \\
\hline Bengkalis & 11.62 & 7.85 & -0.65 & -3.27 & -3.85 & -2.74 & -2.44 & -1.77 & -1.62 \\
\hline Rokan Hilir & -1.30 & -0.01 & 3.65 & 2.38 & 4.81 & 0.52 & 2.30 & 2.03 & -0.12 \\
\hline Kep. Meranti & 6.69 & 6.88 & 6.70 & 4.24 & 4.45 & 2.85 & 3.22 & 3.32 & 4.01 \\
\hline Pekanbaru & 8.98 & 7.54 & 7.82 & 5.59 & 6.90 & 5.57 & 5.96 & 6.10 & 5.39 \\
\hline Dumai & 4.10 & 4.27 & 3.66 & 3.68 & 2.69 & 2.03 & 4.14 & 4.47 & 5.21 \\
\hline
\end{tabular}

Source: Central Statistics Agency of Riau Province (2019)

Based on data on Gross Domestic Product at Constant Prices in Riau Province (table 6), nominal values continued to increase. This increase was not significantly felt by the poor, so that in the analysis year 2010 - 2018, the economic growth had no effect on poverty levels. This shows that economic growth in Riau province is not pro poor or not fully pro-poor. Siregar and Wahyuniarti (2008) have stated that economic growth has a negative and significant correlation to poverty but the impact is not too large or it cannot push the poor to get out of the circle of poverty. Todaro and Smith (2009) have stated that in countries where poverty is decreasing, it experiences sustainable economic growth, but at the same time, economic growth cannot guarantee poverty reduction.

Table 6. Number of poor population and Gross Regional Domestic Product Based on the 2010 Constant Price of

Riau Province in 2010 - 2018

\begin{tabular}{|c|c|c|}
\hline Year & $\begin{array}{c}\text { Total of poor society } \\
\text { (Thousand People) }\end{array}$ & $\begin{array}{c}\text { Gross Regional Domestic Product Based on the 2010 } \\
\text { Constant Price (Million Rupiah) }\end{array}$ \\
\hline 2010 & 558.00 & $388,578,226.96$ \\
\hline 2011 & 472.45 & $410,215,840.21$ \\
\hline 2012 & 476.46 & $425,625,998.51$ \\
\hline 2013 & 511.47 & $436,187,507.42$ \\
\hline 2014 & 498.28 & $447,986,782.47$ \\
\hline 2015 & 531.39 & $448,991,963.52$ \\
\hline 2016 & 515.40 & $458,769,340.07$ \\
\hline 2017 & 514.62 & $471,081,714.33$ \\
\hline 2018 & 500.44 & $482,087,215.74$ \\
\hline
\end{tabular}

Source: Central Statistics Agency of Riau Province (2019)

On the other hand, it is not only statistics that describe economic growth, but also those who feel the distribution of economic growth, whether only a handful of people or a large part of the community. If only a handful of people enjoy it, it can be stated that it has not been able to reduce poverty (Todaro, M. P. and Smith. S.C. (2013).

According to Tambunan (2001) in Maryani (2009), the way to overcome poverty need appropriate interventions and synergies between the government and the private sector (the business community and the community) in reducing poverty in Indonesia. There are three main pillars of poverty reduction strategies, namely: sustainable economic growth and pro-poor, good governance, and social development.

\subsection{Effect of the Human Development Index on Poverty}

The Human Development Index (HDI) influences the poverty rate in Riau Province. Based on the result of the panel data regression, the HDI has a negative effect on poverty with a regression coefficient of -0.559494 and significant at alpha $0.01(1 \%)$. If there is an increase in the development index humans by 1 percent, the poverty level will decrease by -0.559494 . This result is consistent with the research conducted by Prasetyoningrum and Sukmawati (2018) which states that HDI has a significant and negative effect on poverty levels in Indonesia. This indicates that increasing HDI can increase labor productivity.

The Human Development Index in Riau province is increasing every year. In 2010, Riau's HDI was 68.85 
and continued to increase to 72.44 in 2018 (Figure 3). An increase of 3.79 occurred from 2010 to 2018 . The increasing of human development index in Riau province is a form of awareness of all elements in meeting basic life needs such as education, health and decent living needs. The increase is also inseparable from the role of the district/city regional government through various programs such as scholarships for poor families, Regional Health Insurance, Family Hope Assistance, and decent housing assistance for the poor.

Three dimensions of the human development index namely health, education and income play an important role in the process of poverty reduction. Education can increase the ability to absorb knowledge and technology to realize growth and development. Health is the main requirement for increasing productivity. With education and health, income will be achieved to meet needs, and with income also education and health can be achieved optimally (Prasetyoningrum and Sukmawati, 2018).

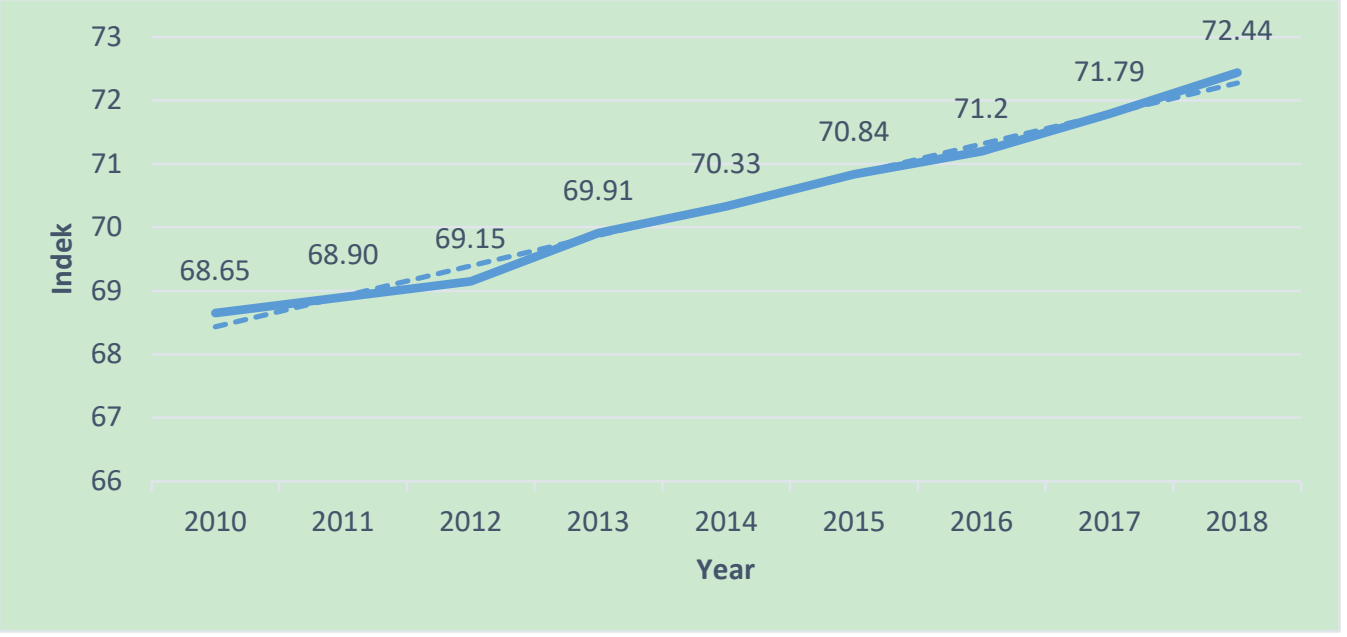

Figure 3, Human Development Index of Riau Province in 2010 - 2018

Source: Central Statistics Agency of Riau Province (2019)

The government is expected to continue to improve the Human Development Index, so that common goals in poverty reduction can be achieved. The increase in the Human Development Index accompanied by increased productivity without being followed by opening up employment opportunities and business opportunities for the people, especially the people of Riau province, will result in unemployment which can lead to poverty.

\section{Conclusion}

From the previous discussion, it can be concluded that: First, economic growth has no effect on a poverty level in Riau province as government policies related to economic growth have not been fully pro-poor. Second, the Human Development Index has an effect on a poverty level in Riau province. This is in accordance with several studies conducted both in the scope of the State and regional scope in Indonesia. Increased public awareness of education and health is a productivity booster to get out of the cycle of poverty. To respond this condition, it is necessary to expand employment opportunities and business opportunities in favor of the population of Riau province, so that the result of economic growth and development can be felt equally.

\section{References}

Ari Kristin Prasetyoningrum and Sulia Sukmawati (2018). Analisis Pengaruh Indeks Pembangunan Manusia, Pertumbuhan Ekonomi dan Pengagguran Terhadap Kemiskinan di Indonesia. Equilibrium. Vol. 6, No. 2.

Central Statistics Agency of Riau Province (2019). Produk Domestik Regional Bruto [Online] Available:https://riau.bps.go.id/subject/52/produk-domestik-regional-bruto.html (Agustus 10, 2019).

Central Statistics Agency of Riau Province (2019). Indek Pembangunan Manusia [Online] Available:https://riau.bps.go.id/subject/26/indeks-pembangunan-manusia.html (Agustus 10, 2019).

Central Statistics Agency of Riau Province (2019). Kemiskinan. [Online] Available: https://riau.bps.go.id/subject/23/kemiskinan.html (Agustus 9, 2019).

Hermanto Siregar dan Dwi Wahyuniarti (2008). Dampak Pertumbuhan Ekonomi Terhadap Penurunan Jumlah Penduduk Miskin. [Online] Available:http://pustaka.blog.mb.ipb.ac.id/files/2010/06/dampak-ptbmbhnek_hermanto.pdf. (November 12, 2019).

Maryanti, Sri. (2009). Analisa Pertumbuhan Ekonomi dan Tingkat Kemiskinan di Provinsi Riau. Pekbis Jurnal, Vol.1, No.3, Hal. 150-158.

Pemerintah Indonesia. (1945). Undang-Undang Dasar negara Indonesia tahun 1945 Pasal 34. Sekretariat Negara. Jakarta. [Online] Availible: https://luk.staff.ugm.ac.id/atur/UUD1945.pdf.

Pemerintah Indonesia. (2004). Rencana Pembangunan Jangka Panjang Negara 2005 - 2025. Sekretariat Negara. 
Jakarta. [Online] Avalible: https://www.bappenas.go.id/files/1814/2057/0437/RPJP 2005-2025.pdf (November 14, 2019).

Pemerintah Indonesia (2009). Rencana Pembangunan Jangka Menengah Nasional tahun 2010 - 2014. Sekretariat Negara. Jakarta.

Pemerintah Indonesia (2014). Rencana Pembangunan Jangka Menengah Nasional tahun 2015 - 2019. Sekretariat Negara. Jakarta.

Pemerintah Indonesia (2010). Peraturan Menteri Dalam Negri Nomor 42 tahun 2010 tentang tim koordinasi penanggulangan kemiskinan Provinsi dan Kabupaten/kota. Sekretariat Negara. Jakarta.

Pemerintah Provinsi Riau (2017). Peraturan Daerah nomor 12 tahun 2017 tentang perubahan atas Peraturan Daerah nomor 9 tahun 2009 tentang Rencana Pembangunan Jangka Panjang Daerah Provinsi Riau tahun 2005 - 2025. Sekretariat Daerah. Pekanbaru.

Pemerintah Provinsi Riau (2009). Rencana PembangunanJangka menengah Daerah provinsi Riau tahun 2010 2014. Sekretariat Daerah. Pekanbaru.

Pemerintah Provinsi Riau (2014). Rencana Pembangunan Jangka menengah Daerah provinsi Riau tahun 2015 2019. Sekretariat Daerah. Pekanbaru.

Pemerintah Provinsi Riau (2018). Peraturan Daerah nomor 1 Tahun 2018 tentang Perubahan atas Peraturan Daerah Provinsi Riau Nomor 7 tahun 2014 tentang Rencana jangka menengah Daerah provinsi Riau tahun 2014 - 2019. Sekretariat Daerah. Pekanbaru.

Sen., Amartya.(1981). Poverty and Famines An Essay on Entitlement and Deprivation. Oxford: Clarendon Press. Sukirno, Sadono. (2006). Ekonomi Pembangunan: Proses, Masalah, dan Dasar Kebijakan. Prenada Media Group. Jakarta.

Todaro, M. P. dan Smith. S.C. (2013). Pembangunan Ekonomi di Dunia Ketiga. Erlangga. Jakarta.

Widarjono, Agus. (2009). Ekonometrika pengantar dan aplikasinya. Yogyakarta. Ekonisia. 